\title{
Denials of Racism in Canadian English Language Textbooks
}

\section{Trevor Gulliver \& Kristy Thurrell}

This critical discourse analysis examines denials of racism in descriptions of Canada and Canadians from English language textbooks. Denials of racism often accompany racist and nationalist discourse, preempting observations of racism. The study finds that in representations of Canada or Canadians, English language texts minimize and downplay racism in Canada's past and present while problematically and uncritically constructing Canadians as committed to multiculturalism and ethnic and racial diversity. The authors echo the call made by the Truth and Reconciliation Commission for antiracist education and education materials that speak frankly of racism in Canadian history.

Cette analyse critique du discours porte sur le déni du racisme dans des descriptions du Canada et des Canadiens tirées de manuels de langue anglaise. Les dénis du racisme accompagnent souvent le discours raciste et nationaliste, empêchant ainsi la reconnaissance du racisme. Cette étude a trouvé que dans leurs représentations du Canada ou des Canadiens, les manuels de langue anglais minimisent ou amoindrissent les cas de racisme dans le passé et le présent tout en proposant, de manière problématique et incontestée, une vision des Canadiens comme étant attachés au multiculturalisme et à la diversité ethnique et raciale. Les auteurs répètent l'appel de la Commission de vérité et de réconciliation pour un enseignement et du matériel pédagogique antiracistes qui dévoilent ouvertement le racisme dans l'histoire canadienne.

KEYWORDS: citizenship, immigration, ESL, LINC

Past generations of newcomers faced injustices and prejudice similar to those experienced by residential school students and their families. More recent immigrants have struggled with racism and misconceptions as they come to take their place in the Canadian nation. (Truth and Reconciliation Commission of Canada, 2015b, p. 307)

This article uses critical discourse analysis (CDA) to examine the ways in which English language textbooks acknowledge or deny the realities of racism in their presentations of contemporary Canada or Canadian history. These textbooks are often used in government-funded language instruction for new immigrants and refugees. We explore the ways in which these denials (or acknowledgements) of racism contribute to (or undermine) a hegemonic understanding of Canada. This study asks the following ques- 
tions: (a) How is racism acknowledged or denied in English language textbooks? and (b) How do these denials serve to marginalize racialized bodies in Canada?

Critical discourse analysis accentuates where systemic social inequities have informed texts and attempts to trace the various ideological and social positions being reproduced. Therefore, it is particularly well suited for making racist discourses more salient. One way CDA effectively identifies racism is by marking various strategies used to deny it. Denials of racism often reproduce racist ideologies and accompany racism both subtle and blatant (van Dijk, 1992, 2004).

If textbooks were to provide an honest narrative of Canada, they would frankly acknowledge racism and the continuing effects of historical injustice. Such texts could provide opportunities for students to critically examine and challenge the dominant narrative by including examples of historical injustice such as Africville, the Chinese Head Tax and Exclusion Act, Indian residential schools, the Komagata Maru incident, the internment of Japanese-Canadians, and Canada's refusal to accept Jewish refugees fleeing the Holocaust during the Second World War, among other incidents, or by including contemporary voices of those who experience racism and injustice.

The vast majority of textbooks in this study speak to a Canada that embraces multiculturalism without engaging with the real and challenging incidents of racism experienced by immigrants, refugees, and others. Furthermore, these texts do not critically examine how white supremacy shapes systems, institutions, language, and education in Canada. This shaping establishes both unmarked Canadian individuals and groups and marked others. Unmarked Canadians experience privilege and centring as their narratives are positioned as normal, legitimate, and objective, while simultaneously, through claims, implications, and denials, marked others experience oppression and marginalization as their narratives are excluded or presented as exceptional, suspect, and subjective. This pattern of representation makes white, male, Anglophone, Christian, able-bodied, socioeconomically advantaged individuals the unmarked Canadian norm.

Marked identities, including but not limited to immigrants, refugees, black Canadians, learners of English, fluent speakers of less-privileged varieties of English, and Muslim Canadians, are discriminated against in society and invisibilized in textbooks in part through denials of their intersectional experiences (Crenshaw, 1991). Identity-based discrimination manifests as inequity in educational and employment opportunities, underrepresentation in political institutions, disproportionately lower pay, higher rates of incarceration, and shorter life expectancy due in part to state-sanctioned violence. Marked identity can have one, many, or all of the elements defined as nondominant by society. Intersectionally unmarked and less marked Canadians perpetrate acts of discrimination against intersectionally marked individuals in myriad ways. 
A note on terminology. There are debates over the terms used to refer to different language teaching contexts and language learners. Most of the textbooks examined in this article refer to their students as learners of English as a second language (ESL). Many of these texts are informed by the Canadian Language Benchmarks, which speaks of English as a second language for adults (ESLA). Alternative terms, such as English as an additional language (EAL), acknowledge that these adult learners may already speak multiple languages. EAL, however, does little to acknowledge current and historical realities of racism and systemic white supremacy in Canada. Furthermore, the term EAL fails to reflect that languages other than English and French have been and continue to be spoken in the territory now known as Canada. It fails to acknowledge that speakers of dominant languages, such as English and French, have perpetuated a "linguistic genocide" (Skutnabb-Kangas, 2000) resulting in the eradication or endangerment of hundreds of Aboriginal languages in North America. It does little to undermine the racism through which English and French become "Canadian" languages while other languages, such as Chinese, which have been spoken in the territory now known as Canada since prior to Confederation, remain otherwise. As Stanley (2006) muses, "One wonders how long it takes for a language to become Canadian" (p. 46) and indeed who chooses. In order to accentuate the racist, colonizing, and globalizing projects that led to English's unique position in the world as experienced in Canada, in this article we will use the term English as a colonizing language (ECL).

\section{Antiracist Education and the Truth and Reconciliation Commission}

The Truth and Reconciliation Commission of Canada (TRC) provides a striking condemnation of racism in Canada and offers an example of an honest history of Indian residential schools that speaks to a legacy of racism, abuse, genocide, and forced assimilation (TRC 2015a, 2015b). The TRC issued 94 "calls to action" urging Canadians to repair the damage done by years of physical and sexual abuse (Mas, 2015; TRC, 2015c). Call to Action 93 asks the Canadian government to revise citizenship texts to "reflect a more inclusive history of the diverse Aboriginal peoples of Canada" (TRC, 2015c, p. 14). Other calls for action ask for education systems that are inclusive of Aboriginal students and perspectives. The TRC finds that the teaching of this more inclusive history would require professionals in various contexts to receive antiracism training.

After seven years of documenting the history of and receiving statements from the survivors of the Indian residential school system, the TRC released its final report in 2015. It found that the "residential school system was based primarily on the racist belief in the superiority of settlers and the inferiority of Aboriginal cultures" (TRC, 2015a, p. 114). Furthermore, 
the commission found that many Aboriginal people continue to regularly experience "intense racism" and "systemic and other forms of discrimination" (TRC, 2015a, p. 3) in Canada. The report declares a lack of awareness of residential schools and the ongoing racism faced by First Nations' individuals and communities, which "reinforces racist attitudes and fuels civic distrust between Aboriginal peoples and other Canadians" (TRC, 2015b, p. 8). Therefore, it calls for education in various sectors in order to overcome this continued racism.

\section{The TRC and Textbooks}

The TRC (2015b) names the discrimination enacted by dominant Canadians against First Nations, Métis, and Inuit individuals and communities as furthered through absent and flawed representations in textbooks. It speaks to how both racist representations in and exclusions from Canadian textbooks denigrate First Nations. The TRC (2015b) found that school textbooks used in Canada prior to 1970 "depicted Aboriginal peoples as being either savage warriors or onlookers who were irrelevant to the more important history of Canada: the story of European settlement" (p. 286). In the 1980s, Canadian textbooks included more positive representations of Aboriginal people, but reproduced racism by shirking the responsibility for speaking about colonization and emphasizing "poverty and social dysfunction in Aboriginal communities [...] without any historical context to help students understand how or why these happened" (TRC, 2015b, p. 286). In the 1990s, textbooks framed counterhegemonic narratives by Aboriginal peoples as protests or dissatisfaction with the Canadian government. Lacking presentations of colonization, readers of these textbooks were unable to contextualize the struggles of Aboriginal people for rights. The report finds that "although textbooks have become more inclusive of Aboriginal perspectives over the past three decades, the role of Aboriginal people in Canadian history during much of the twentieth century remains invisible" (p. 287). Textual presentations of Aboriginal peoples reproduce a white supremacist perspective by introducing them as existing in a state of nature prior to contact with Europeans. This presentation denies agency and declares Europeans the catalyst for Aboriginal actualization. The exclusion of chronologically thorough and varied histories of Aboriginal peoples denies their continued and ongoing experience of colonization. Therefore, the Commission calls for histories of Canada that include the voices of Aboriginal peoples and for education systems that are inclusive of Aboriginal students and perspectives.

\section{Discourses in Language Textbooks}

ECL textbooks are sites through which powerful and dominant discourses enter the classroom and are introduced to refugees and immigrants. The texts, in fact, often assume an explicit pedagogical responsibility to dissemi- 
nate discourses on citizenship and the nation, making them a significant site for interrogation. Ndura (2004) finds that in ECL classrooms "instructional materials play the role of cultural mediators as they transmit overt and covert societal values, assumptions and images" (p. 143). Similarly, Suaysuwan and Kapitzke (2005) state that "students not only learn subject matter from textbooks, but they also acquire values, interests, and knowledge that form desires, habits, and identities" (p. 79). It is, therefore, "very important to examine the content, activities, and ideologies represented in textbooks" (Duff \& Uchida, 1997, pp. 470-471) and the role they play in reproducing dominant ideologies (van Dijk, 2004). Van Dijk (2001) finds that discourses become influential when (a) they are obligatory; (b) they come from "authoritative, trustworthy, or credible sources, such as scholars, experts, professionals, or reliable media" (p. 357); (c) "there are no public discourses or media that may provide information from which alternative beliefs may be derived" ( $\mathrm{p}$. 357); and (d) they are unchallenged by prior knowledge. ECL textbooks may be obligatory parts of government-funded language instruction available to immigrants and refugees to Canada. Textbooks are both presented and present themselves as authoritative. They reproduce hegemonic understandings of Canada that are infrequently challenged in national media or public discourse. They are often produced for people who are new immigrants and refugees to Canada and who may have or are positioned as having less prior knowledge that could undermine these nationalist and racist narratives. In an ECL context, unmarked Canadians present seemingly authoritative texts to those positioned as marked by the texts, reproducing racism while providing little space to undermine it.

ECL textbooks as a discourse type can be quite influential but act in relationship with students' ability to resist the values, interests, and knowledge presented. Canagarajah (1993) notes resistance to the westernizing discourses he identifies in textbooks in Sri Lanka; in the margins of the textbooks were slogans promoting a separate Tamil state, and some of the illustrations had been touched up to portray well-known Tamil resistance fighters. Despite these critical notes in the margins, in interviews, students did not feel that U.S. culture was imposed on them through the texts and found the texts of interest, even while noticing the racism, social inequality, and imperialism within them (p. 619). Only 1 of 22 students Canagarajah interviewed thought that the texts "posed a cultural threat" (p. 620), which, as he states, "unwittingly leads students to participate in their own domination" (p. 601).

Research on Canadian contexts has examined the ways in which representations of national culture attempt to teach "Canada" to immigrants and refugees while positioning them, particularly those with intersectionally marked identities, as lacking in relevant cultural understandings (Derwing \& Thomson, 2005; Fleming, 2003; Gulliver, 2010, 2011; Ilieva, 2000, 2001; Thomson \& Derwing, 2004). Thomson and Derwing (2004) found that a third of the texts in use in Language Instruction for Newcomers to Canada (LINC) 
classrooms contained only the most superficial references to Canada and that many of the texts "actually had little or no substantive Canadian content" (p. 23); many of the texts could be set anywhere in North America were it not for the use of Canadian place names and Canadian money. Gulliver (2011) finds that these same textbooks are infused with a form of banal nationalism that constantly marks the nation through flags, maps, and other symbols. Culture, then, is presented as trivial facts as well as stereotyped and nationalized values and markings.

Ilieva (2001), doing research on the Canadian context, considers culture "a negotiation of meanings among particular individuals in particular communities locked in an interplay of power relations" (p. 7); this understanding of culture leads her to argue for the introduction of ethnographic techniques when helping students develop cultural knowledge. Such an approach would, if done well, lead to immigrant and refugee students having complex, nuanced, and personal understandings of Canadian identity that move far beyond flags and trivia.

ECL textbooks legitimize hegemonic and nationalistic representations of Canada while delegitimizing and invisibilizing the lived experiences of immigrants and refugees. Gulliver (2010) finds that Canadian ECL textbooks imagined Canada as a "redeemer of immigrant newcomers" and "overwhelmingly represent hard-working immigrant newcomers as successful and appreciative of the opportunities provided to them by Canada" (p. 725). These immigrant success stories also implied, or explicitly stated, that immigrants and refugees who were not successful in Canada were not hard-working enough. Fleming (2012) found that the Canadian Language Benchmarks, an official national assessment and curricular document, positioned "ESL learners as powerless and passive. They are viewed as recipients of programming that is designed to normalize them into a dominant culture ... through normative references to what it means to be a Canadian" (p. 610).

\section{Nation and Hegemony in Language Textbooks}

Concerns about hegemonic discourses in texts are widespread and of importance to language teachers in a variety of contexts, including those in which students are immigrants or refugees to Canada. ECL textbooks may present students with discourses that support national policies, globalization, and/ or westernization. According to van Dijk (2004), the influential discourses presented in textbooks are shaped by and involved in the reproduction of dominant and hegemonic ideologies that promote racialized nationalism. Researchers using discourse analysis (sometimes combined with critical ethnography) have found, in textbooks from various educational contexts, nationalizing discourses related to areas of economics, the natural environment, social control, gender roles, consumption, and everyday life (Chen, 2005; Lee, 2005; Liu, 2005; Suaysuwan \& Kapitzke, 2005). 
In a study of Thai ECL textbooks, Suaysuwan and Kapitzke (2005) found that with industrialization, texts and images of daily life shifted from presentations of family-oriented, gender-segregated, village life with parents dutifully engaged in agriculture to more gender-integrated presentations of children as autonomous, urban, and consumption-oriented. This shift led them to argue that "in Thai English language lessons, hegemonic cogency in textbooks encourages child readers to adopt Western ideas, values, and practices such as those of consumer cultures" (p. 95).

Alongside these nationalizing, "westernizing," or globalizing discourses, ECL textbooks contain racializing discourses that situate and position students vis-à-vis membership in the imagined community. Canagarajah (1993) finds that the American ECL textbooks used at one university in Sri Lanka assume "an urbanized, technocratic, Western culture that is alien to the students" (p. 609) and promote consumerism, industry, and upward social mobility with traces of racism while presenting themselves as value-free. Ndura (2004) found that ECL texts used in elementary and secondary schools in the USA contained gendering, racializing, and exoticizing stereotypes and avoided any discussion of the pernicious effects of racism in the present, even as part of discussions in the text on topics such as the Civil Rights Movement and the Universal Declaration of Human Rights (p. 148).

State-sanctioned ideologies are not exclusive to ECL textbooks. Liu (2005) finds that Chinese language textbooks reproduce discourses on the values of love of the country, work or sacrifice for the country, diligence, collective spirit, and the happy life people enjoy "in this country." Lee (2005) analyzes a South Korean reading text, finding that it describes environmental destruction and devastation in ways that minimize the effects of industrial pollution, implying instead that people who visit the countryside are responsible for environmental devastation.

The examples cited above originate in a variety of teaching contexts and connect with differing sociopolitical concerns. The issues involved may vary widely depending on the status of the learner in the country, the status of the language in the country, whether they involve first or second languages, and threats to the learners and language. We mention them here to show that concerns about hegemonic discourses in texts are widespread and of importance to language teachers in a variety of contexts, including those in which the students are immigrants or refugees to Canada.

\section{Nationalism and Racism}

Goldberg (2002) argues that race and the modern state are "co-articulated" (p. 4) through racial characterizations, marginalizations, exploitations, and exclusions (Goldberg, 2002, p. 4) and "the internalisations of exclusions" (p. 9). The social construction of racialized identity occurs through division or separation, naturalization, and essentialization (Montgomery, 2005, 
p. 319) with the effect of producing a "racially configured homogeneity," which has been promoted as part of modern statehood (Goldberg, 2002, p. 5). The invention of nation and the invention of race both involve discursively marking in-groups and out-groups and often positively presenting the in-group while negatively presenting the out-group (Miles \& Brown, 2003, p. 142).

Such racializing representations of nation and national identity accomplish a kind of "place making" - "a construction, rather than merely a discovery, of difference" (Gupta \& Ferguson, 1997b, p. 13) that confuses an often unstable and mobile relation between subject and community for a fixed and rooted membership. The ubiquity of the concept of nationhood involves forgetting those who find themselves marginalized within or excluded from nations. The possibility of imagining yourself regionally, transnationally, or as nationless is circumscribed by the widespread acceptance of nation as a universally applicable label. Gupta and Ferguson (1997a) describe this as a fiction that sees cultures "as discrete, objectlike phenomena occupying discrete spaces [that] becomes implausible for those who inhabit the borderlands" (p. 34).

Critical analysis of discourses on race and nation bear this out. Nationalist texts participate in the racializing of nationhood through strategies of mythical expansion, collective remembrance, construction of national uniqueness and intranational sameness, and the banal marking of a national body. Texts make use of positive self-presentation and negative other presentation to downplay racism while, simultaneously, "othering" immigrants and refugees (de Cillia, Reisigl, \& Wodak, 1999; van Dijk, 2004).

\section{Racism and Its Denial}

One of the crucial properties of contemporary racism is its denial. (van Dijk, 1992, p. 87)

Some critical discourse analysts have argued that, due to the social stigma regarding overt expressions of racial prejudice (van Dijk, 1992) and national pride (Condor, 2000), discourses on race or nationalism are most marked by their denial. These denials of racism legitimate the negative representations by attempting to preempt claims that this "negative talk about minority groups or immigrants may be heard as biased, prejudiced or racist" (van Dijk, 1992, p. 115). In other writing, van Dijk $(2002,2006)$ analyzes the "ideological" processes through which a group imagines and positively represents itself and, at the same time, imagines others as outside of the group and as having negative qualities. Such processes often work to construct and positively present a group as a nationalized "we-community" while either implicitly or explicitly constructing and negatively presenting another group. 


\section{Analysis}

Through a survey of LINC teachers (Gulliver, 2009), we selected 24 textbooks used in ECL teaching in Canada (Acosta, 1995; Azar, 1999, 2003; Azar \& Hagen, 2006; Bates, 1991; Berish \& Thibaudeau, 1997a, 1997b, 1997c, 1997d, 1998a, 1998b, 1999; Cameron \& Derwing, 2004; Carver, Cooper, \& FotinosRiggs, 1993; Kingwell, Bonkowski, Stephenson, \& Holmes, 2005; Molinsky \& Bliss, 1994, 2001; Olsen, 1984; Shapiro \& Adelson-Goldstein, 1999; Swan \& Walter, 2001; White, 1997; Zuern, 2003, 2005, 2007). Although many of these textbooks contained little sustained discourse and some entirely lacked a focus on Canada, several of them acknowledged, discussed, and/or denied racism in Canada: Canadian Snapshots (Kingwell et al., 2005), Being Canadian (Cameron \& Derwing, 2004, 2010); Ontario Reader 2003 and Ontario Reader 2007 (Zuern, 2003, 2007) make reference, even if euphemistically, to racism. From these five textbooks, we have identified passages that referred to racism (or prejudice, discrimination, and inequity) or referred to Canada as being multicultural, antiracist, or tolerant of others. We have also selected descriptions of historical events related to social relations. We have analyzed each of these texts for the extent to which racism is acknowledged or denied, confronted or downplayed. Drawing from van Dijk (1992, 2004), we have roughly grouped the common types of denials seen in textbooks:

- Localization. Racism may be localized as belonging to a specific place but not to the country as a whole. In the context of claims that Canadians are committed to diversity and that Canada is multicultural, placing racist beliefs in a specific and smaller region of Canada is a form of localization.

- Racism as a property of others. Racism may be denied through transfer moves in which the others' racism is discussed but emphasis is put on the relative lack of racism in Canada in comparison to "other countries."

- Denial of racist intent. A denial of racist intentions may involve an acknowledgement that an incident or problem occurs but a denial that the intention of the social actors is racist.

- Euphemistic reframing. Euphemistic reframing of racism may involve the avoidance of the term "racism" in favour of a less specific term such as "discrimination" or "stereotyping." Such reframing of racism may also involve the use of passive sentences that leave social agents unnamed (e.g., "they were discriminated against") or nominalizations (e.g., "discrimination occurred").

- Individualization. Individualization is a denial of racism in which racism is cast as a property of individual members of the group while the group itself is presented as not racist. Presenting racism as "prejudice" is a form of individualization in that it presents it as a personal belief, not systemic and structural inequality.

- Historicization. Texts may discursively distance a social group from racism by representing racism as something that happened in the past. An- 
other form of distancing occurs when texts acknowledge past "prejudice" but contrast it with claims of a less racist present.

- Mitigating circumstances. Mitigating circumstances, usually in the form of statements that give context to racist incidents, may be brought in to explain an action so that it is not perceived as clearly racist but possibly also a result of other causes.

Through strategies like these, racism is denied or acknowledged to a limited extent, but even then is posited as a past event that is better now, something that happens elsewhere, or an individual belief rather than a systemic problem (van Dijk, 1992; Wodak, 2006).

\section{Racism and Its Denial in Identified Texts}

Denials of racism often contain more than one form of denial. In what follows, we have attempted to separate out examples of each form of denial while avoiding repetition when a text employs multiple examples.

Localizing racism. Zuern (2007) introduces Michaelle Jean, the Governor General of Canada, as "the third woman and the first black person to hold this influential position" (p. 65). The text reads: "The family settled in Thetford Mines, Quebec. There, they were one of the few non-white families in town. Young Michaelle had to cope with racism" (p. 65). This acknowledgement of racism localizes it in a small town, describes the mitigating circumstances of the Jean family being "one of the few non-white families in town" (p. 65), and places it in the past of Michaelle Jean's childhood. Through the lack of specificity, racism, even when it is acknowledged here, remains abstract and impersonal.

Historicizing racism. Several texts refer to discrimination against Chinese immigrants. In "Forgotten Story Goes to Court" (Zuern, 2003, p. 57), the story is personalized through the presentation of the granddaughter of an immigrant to Canada from China who discusses the effects that the head tax had on her grandfather and the distress it caused him: "Yam's grandfather was cut off from his family in China until 1947" (p. 57). Despite the call within the text for compensation from the federal government, the text downplays racism in a number of ways. Sixteen-year-old Debbie Yam is indirectly reported as considering the head tax "an act of discrimination," but the closest the authorial voice of the article comes to calling the head tax racist is when it refers to "victims of the head tax" (p. 65, emphasis added). Furthermore, the racism of the head tax is clearly situated in the past through the use of time clauses such as "in 1923," "at that time," "later in 1923," "until 1947," and "between 1885 and 1923" (p. 57). It notes "many people have forgotten" that this discrimination took place and that "most young people don't know about this" ( $p$. 57). Yam is quoted as saying: "'History is very important,' Yam says. 'If you know the history and the mistakes, you can learn from the mistakes'" (p. 57). This characterization of the head tax as a "mistake" further downplays an explicitly racist policy intentionally created to exclude immigrants from China. 
Another article on the same page of Ontario Reader (Zuern, 2003) titled "Hard Life for Early Chinese Immigrants" (p. 57) also situates racism as something that happened in the past. Describing early Chinese immigrants who came to Canada to work in gold mines or build the B.C. section of the Canadian Pacific Railway, the article acknowledges dangerous and difficult working conditions. It also contains an acknowledgement, of sorts, of racism: "Many Canadians did not want Chinese in Canada. The government passed laws to keep out Chinese immigrants" (p. 57). The article continues with a discussion of the head tax, which it refers to as a "discriminatory law" (p. 57).

The article situates "prejudice" as something that happened in the past. It begins, "Every year, thousands of new immigrants arrive from China. But it wasn't always so easy for Chinese newcomers" (Zuern, 2003, p. 57). It ends by noting that since the repeal of the head tax in 1947 and the removal of other restrictions in 1967 "thousands of Chinese have immigrated to Canada" (p. 57). There is no discussion of present-day "discrimination" or any possible current racism on the part of "many Canadians." Racism remains a matter of "prejudice" and "discrimination" but is not explicitly characterized as racism. Furthermore, the characterization of arrival and integration into a new country as "so easy" is dismissive of the hardships and difficulties many current immigrants and refugees must overcome.

Mitigating circumstances. This discursive strategy of presenting racism as something that happened in the past also appears in two readings on "Canadian Issues" in Being Canadian (Cameron \& Derwing, 2010). A text titled "Chinese Canadians" explains:

Many Chinese men came to Canada in the nineteenth century to help build the railway. When it was completed, a lot of them stayed, mostly in British Columbia. The federal government at the time would not allow the men to bring their families to Canada unless they paid a head tax. (Cameron \& Derwing, 2010, p. 56)

As no other explanation is given as to why these laws were enacted, the words "a lot of them stayed, mostly in British Columbia" appear as a possible mitigating circumstance for the discriminatory laws put in place by "the federal government at the time" (Cameron \& Derwing, 2010, p. 56). The article then notes that "it was not until 1947 that Chinese Canadians were given most of the rights enjoyed by other Canadians" and that other "restrictions" were lifted in 1967 (p. 56, emphasis in original). The rest of the reading is devoted to explaining how "Canada has come a long way in the last few decades. There is now less discrimination" (p. 56), exemplified by the mention of David See-Chi Lam as lieutenant-governor of British Columbia and "Adrienne Clarkson, who came to Canada as a refugee from Hong Kong" as Governor General of Canada (p. 57). These "additions" are a form of recontextualization of the event, and tenuous ones in that they have little direct relationship to the events being described. Such claims to a less discrimina- 
tory present often occur after even the most ambiguous acknowledgements of discrimination in the past.

On the following page of Being Canadian, an article titled "Japanese Canadians" follows a remarkably similar rhetorical style (Cameron \& Derwing, 2010). It begins with a statement about the numbers of Japanese Canadians living in Canada in the 1940s. The attack on Pearl Harbor is mentioned, acting as a mitigating circumstance for internment. The text then describes how "the Canadian government sent Japanese to work camps in the interior of British Columbia and in Alberta" (p. 57). Other than the attack on Pearl Harbor, no motive is given for the government's actions. "Discrimination during the war" is only acknowledged in the context of an apology by the federal government. In concluding the article by noting that "the federal government apologized and gave some money to those people who were discriminated against" (p. 57), once again evidence of a less discriminatory present serves to distance Canada from past discrimination.

In Cameron \& Derwing (2010), the terrorist attack on the World Trade Center on September 11, 2001 appears as a mitigating circumstance to explain Islamophobia. A text titled "Discrimination" declares that "world events often trigger discrimination" (p. 69) and mentions discrimination against "many Arab and Muslim Canadians ... even though they had nothing to do with the terrorist attacks in the United States" (p. 69). The earlier (second) edition of the same textbook (Cameron \& Derwing, 2004) included a reading titled "The Effects of September 11, 2001," in which racial profiling is explained (p. 95). The terrorist attack on September 11th is assigned as a cause of racial profiling and discrimination: "Unfortunately, one of the consequences of September 11 is racial profiling and discrimination towards visible minorities" (Cameron \& Derwing, 2004, p. 95). This passage, absent in the third edition, provides mitigating circumstances to explain Islamophobia. Furthermore, in much the same way as other texts fix the head tax in a historical context to mitigate it, these texts fix Islamophobia in a post-9/11 world.

Euphemisms for racism. Racism is rarely mentioned as a cause of "discrimination" in identified ECL textbooks. Being Canadian's "Canadian Issue" reading mentions more recent "discrimination" (Cameron \& Derwing, 2010). It begins by citing a survey of students in an ECL class regarding discrimination. Nine of the 14 "said that there is some discrimination on the basis of sex, skin colour, nationality, and language skills" in Canada (p. 69). Student readers are then asked, "How many people in your class have been discriminated against?" (p. 69). This acknowledgement that "skin colour" might serve as the basis for discrimination is rare in identified textbooks. The article then describes a "case of discrimination" in which Sikh men were denied entry into "some branches of the Royal Canadian Legion." The article presents the Legion member's argument that "it is a sign of respect to remove headgear when entering the Legion" and explains the Sikhs' religious requirements to wear the turban (p.69). No motive for this discrimination other than tradition 
and respect for Legion customs is mentioned. Racism and white cultural superiority are often euphemized with words such as "tradition" or "respect." Furthermore, the possibility that racism could motivate this discrimination is not mentioned.

Canadians as nonracist. Canadian ECL textbooks represent Canada as being diverse and multicultural and Canadians as being supportive of that multiculturalism. Throughout Acosta (1995), Canada is represented as diverse. On one page, a photo of a smiling RCMP officer wearing a turban bears the caption "This RCMP officer is Sikh. He wears a turban instead of a hat" (p. 17). Even on the following page in which the RCMP uniform is discussed, there is no mention of the very public debate that took place in Canadian media over allowing the wearing of the turban by Sikh officers. The proclamations of multiculturalism in identified textbooks are rarely accompanied by substantive discussion of the challenges faced by new Canadians and the limits to Canadians' commitments. Hypocritically, the racialized bodies once marginalized by racism become presented as evidence of Canada's multiculturalism.

Cameron and Derwing (2010) introduce the Canadian Multiculturalism Act and invite discussion of multiculturalism (pp. 66-67). The text states that "61 percent of Canadians support the multiculturalism policy" and that " 51 percent believe that recent immigrants should have as much say about the future of Canada as people who were born and raised here" (p. 66). Neither the text nor the comprehension questions that follow invite discussion of whether these numbers demonstrate that Canadians value multiculturalism. Furthermore, one might ask how the lived experiences of new immigrants or refugees might be affected by the 39 percent who don't support the policy, or the 49 percent who do not support their democratic rights.

Not only were Canadians presented as committed to diversity, in some texts they were represented as more committed to diversity than Americans:

- "In a recent poll, nearly three-quarters said they believe Canadian culture is different from the culture of the United States. They said that Canadian history, geography, political systems, and treatment of minorities contribute to those differences" (Berish \& Thibaudeau, 1998b, p. 15).

- "Many Canadians think of themselves as tolerant, peace-loving, and less violent than their American neighbours" (Berish \& Thibaudeau, 1998a, p. 21).

Focusing on Canadians' commitments to multiculturalism can be a positive self-presentation that preemptively denies racism, while pointing toward the racism of others is evasive. Both distract from the realities of racism in Canada. Furthermore, as representations of Canadianness centre white, male, Anglophone Canadians and marginally position others, claims to the tolerance of Canadians ironically further white supremacy in Canada. 
The disappearance of Aboriginal peoples. Discourses identified by the TRC in representations of Aboriginal peoples can be found in ECL textbooks, which (a) introduce Aboriginal Peoples and their culture before colonization, (b) depict initial colonization as relatively benign, (c) lack representations of Aboriginal peoples in the majority of Canadian history, and (d) reintroduce Aboriginal peoples as "as a social and economic problem that must be solved" (TRC, 2015b, p. 235). A single chapter in Cameron and Derwing (2010) exemplifies the pattern named above. It describes Native people and Inuit as living in nature prior to colonization with little reference to anything that could be called a history. It then describes the period of colonization as a time in which Native people taught Europeans to survive and traded with them. Native people became guides and brides to the Europeans. Other readings in the same chapter acknowledge that "Europeans brought serious diseases" and that "tens of thousands of Native people died" (p. 21). It specifically references the abuse suffered by children in the residential schools. It concludes with a paragraph that mention "serious social problems including discrimination, poor education, alcoholism, and high unemployment" (p. 22) but also attempts to counter negative stereotypes prevalent in Canada.

As with the vast majority of ECL textbooks, in this chapter racism is not named as such. Passive sentences allow agents to be elided so that "Indians were forced off their lands" (Cameron \& Derwing, 2010, p. 21) and "Native children were forced to leave their families" (p. 22). Texts that follow the pattern described above, where racism is located in the past, note more recent apologies that insulate present-day Canada from this racism. Existing prejudice is localized (and not nationalized) in sentences such as "there are some people who have a stereotyped idea about Native people" (p. 22).

Acknowledging racism. Canadian Snapshots (Kingwell et al., 2005) provides a more inclusive presentation of Canada by discussing both multiculturalism and racism. Through this approach student readers are encouraged to engage in critical discussions about representations and invited to question or critique positive constructions of "Canadian" identity. Texts that present more nuanced and complex understandings of race and nation provide a space with the potential to disrupt hegemonic and racist discourses.

In a chapter titled "Canadian Mosaic," Canadian Snapshots (Kingwell et al., 2005) includes a claim that "Canada is one of the most multicultural countries in the world and one of the most desired places for immigration" (p. 3) along with a maple-leaf flagged "culture note" on establishment of "policy of multiculturalism in 1971" (p. 6). However, the textbook also contains texts that discuss racism in Canada (pp. 13-15) and invites student readers to write a letter to a friend describing "two cultural challenges your friend might face in Canada" (p. 6). In doing so, the texts repeat claims about Canadian multiculturalism but do not present them as uncontested knowledge.

Canadian Snapshots (Kingwell et al., 2005) contains three stories about the experiences of individual immigrants to Canada (pp. 13-14). The first story 
describes Mading, a refugee from Sudan now living in Surrey, B.C., who experienced racist violence after arriving in Canada but now works as a facilitator at an Immigrant Services Society program. Unlike in the majority of texts that describes struggles in Canada, Mading, characterizing Canada as a mountain, implies that Canada is the cause of the struggles: "This is Mount Canada. I was at the bottom of the mountain when I came here at 13. Racism and bullying were so overwhelming I couldn't climb the mountain. So I went back down" (Kingwell et al., 2005, p. 13).

The stories of Francisco, a refugee from Guatemala, and Nathalie Lozano, a refugee from Columbia, describe experiences that further disrupt the typical immigrant success stories often included in ECL textbooks (Gulliver, 2010). Francisco left a higher socioeconomic status in exchange for the relative safety of Canada. Unlike the many immigrant experience stories that focused on material wealth, Francisco argues "material things aren't worth anything. Not without peace" (Kingwell et al., 2005, p. 13). Peers incorrectly identified Nathalie as "a Hindu," taunting and subjecting her to racist violence: "I didn't know even how to say hello. So I didn't talk to them and they thought I was being rude. After class they kicked me. That day I cried so much" (Kingwell et al., 2005, p. 14).

Canadian Snapshots (Kingwell et al., 2005) acknowledges racism in productive ways by centring passages that highlight voices of refugees and immigrants who express complex and challenging ideas of what it means to integrate into Canadian society.

\section{Discussion and Conclusion}

How do we reconcile? How do we have those difficult conversations that say that you are implicated in my struggle? You have privilege that I don't. You have an education that I was not privy to. (Akua Benjamin, quoted in TRC, 2015b, p. 312)

Many Canadians feel that Canadian identity and cultural identity is somehow defined by this universal humanism ... They deny colonialism and racism and [attitudes of] white superiority ... whose legacy we continue to see today.... It's a very toxic legacy. (Ali Kazimi, quoted in TRC, 2015b, p. 313)

The Chinese, along with Indigenous children, were secluded in the education system for so many years ... there's been a constant narrative of systemic racism, exclusion, and exploitation.... I think [we need to talk about] remembrance, resistance, and reconciliation. (Winnie Ng, quoted in TRC, 2015b, p. 313)

The above quotations from "newcomers to Canada" provide a powerful condemnation of denied racism, of limited history, and of excluded narratives; 
the impact on them mirrors that of the voices of Aboriginal peoples who have been silenced by a white supremacist Canadian history. The shared experience of "traumatic memories of colonial violence, racism, and oppression" (TRC 2015b, p. 312) creates opportunities for honest discussion of racism, privilege, and power. Honest conversations should expect that "newcomers" might not experience marked identity similarly, and that learners of English as a colonizing language may differ in their desire to assimilate into unmarked "Canada." For example, immigrants who chose Canada might feel differently connected than refugees or asylum seekers. The TRC calls for newcomers to Canada to find common ground with Aboriginal peoples by "learning about the history of Aboriginal peoples and finding ways to build stronger relationships of solidarity with them" (TRC, 2015b, p. 312). ECL educators are uniquely situated to facilitate honest and nuanced conversations on these topics, but are not supported by ECL textbooks to do so.

In the textbooks studied, the voices of marked Canadians, including many immigrants, refugees, and Aboriginal peoples, are mostly reported indirectly or are directly reported only in short quotes that support the argument being made throughout the text. The clearest acknowledgements of racism in the identified texts occurred when texts presented the uninterrupted voices of nonwhite Canadians at greater length, as can be seen in the immigrant experience stories from Canadian Snapshots (Kingwell et al., 2005). Unlike findings in textbooks that assume the reader to be the unmarked citizen (van Dijk, 2004), the identified ECL textbooks in this study incorporate the voices of marked Canadians, immigrants, and refugees to support the message of the text. The texts position their readers as immigrant and refugee students who are assumed to need to learn about "our" good things.

Texts imagine Canada as uniquely multicultural. Racism is denied, in part, through a continual emphasis on "Canadian" diversity and a claim to a positive valuation of multiculturalism and inclusiveness. The racialized bodies of marked Canadians appear in the text as evidence of Canada's multiculturalism, with negative representations of others usually being subtle or implied when they appeared at all. Claims to Canada's multiculturalism may preempt observations of racism in Canada's past and present. The denial of racism found in texts can at first provide a false sense of security, but eventually the contradiction between text and lived experience serves to marginalize and invalidate the lived experiences of immigrants and refugees. In turn, denials can alienate individuals, silence counternarratives, and undermine self-advocacy.

This study examines racist and racializing discourses in textbooks and the routine denials that accompany them. The same discourses and denials of racism are widely articulated outside of the classroom and can be found in government-produced citizenship material, media, and other educational texts. Canadians, including the authors of this study, the authors of the textbooks examined, and ECL teachers often reproduce these racist discourses. As 
two white researchers and writers, we recognize the privileged lens through which we have addressed the reproduction of racism and white supremacy through ECL texts, and we recognize that we benefit from racist systems we attempt to critique. We hope to encourage critical examination of the role of English in the communities in which we live, work, teach, and learn, while we appreciate the irony that we are writing in the colonizing language of English.

ECL teachers in Canada have an obligation to consider ways in which representations of Canada perpetuate and support racism by denying its existence. ECL textbooks represent Canada as a bilingual and multicultural nation in which racism and sexism are not significant current realities. Within these identified textbooks, marginalizing and exclusionary discourses exist alongside of the proclamations of welcome and inclusiveness. Racism is taught to students by discourses that construct hegemonic national identities and representations of culture. The "better" Canada that these texts imagine may be an attractive one, but it is irresponsible to present it uncritically and to ignore the extent to which white supremacist stories of Canada continue to dominate in texts, classrooms, and society.

\section{The Authors}

Trevor Gulliver has been a professor in the School of Education of Bishop's University since 2009, where he prepares teachers of English as a second language for Quebec public schools. His research explores issues of power and identity in language learning and teaching.

Kristy Thurrell is an antiracist educator and history teacher. Her research interests include antioppression education, critical whiteness studies, decolonization, social movements, and social change.

\section{References}

Acosta, J. (1995). Canada coast to coast. Scarborough, ON: Nelson Canada.

Azar, B. S. (1999). Understanding and using English grammar (3rd ed.). Upper Saddle River, NJ: Prentice-Hall.

Azar, B. S. (2003). Fundamentals of English grammar (3rd ed.). White Plains, NY: Longman.

Azar, B. S. \& Hagen, S. A. (2006). Basic English grammar (3rd ed.). White Plains, NY: Longman.

Bates, S. (1991). Amazing! Canadian newspaper stories. Scarborough, ON: Prentice-Hall Canada.

Berish, L., \& Thibaudeau, S. (1997a). Canadian concepts 1 (2nd ed.). Scarborough, ON: Prentice

Hall Allyn \& Bacon Canada.

Berish, L., \& Thibaudeau, S. (1997b). Canadian concepts 2 (2nd ed.). Scarborough, ON: Prentice Hall Allyn \& Bacon Canada.

Berish, L., \& Thibaudeau, S. (1997c). Canadian concepts 3 (2nd ed.). Scarborough, ON: Prentice Hall Allyn \& Bacon Canada.

Berish, L., \& Thibaudeau, S. (1997d). Canadian concepts 4 (2nd ed.). Scarborough, ON: Prentice Hall Allyn \& Bacon Canada.

Berish, L., \& Thibaudeau, S. (1998a). Canadian concepts 5 (2nd ed.). Scarborough, ON: Prentice Hall Allyn \& Bacon Canada.

Berish, L., \& Thibaudeau, S. (1998b). Canadian concepts 6 (2nd ed.). Scarborough, ON: Prentice Hall Allyn \& Bacon Canada.

Berish, L. \& Thibaudeau, S. (1999). Amazing stories to tell and retell 1. Boston, MA: Houghton Mifflin Company. 
Cameron, J., \& Derwing, T. (2004). Being Canadian (2nd ed.). Saint-Laurent, QC: Pearson Longman ESL.

Cameron, J., \& Derwing, T. (2010). Being Canadian (3rd ed.). Saint-Laurent, QC: Pearson Longman ESL.

Canagarajah, S. (1993). Critical ethnography of a Sri Lankan classroom: Ambiguities in student opposition to reproduction through ESOL. TESOL Quarterly, 27(4), 601-626. https://doi. org $/ 10.2307 / 3587398$

Carver, T. K., Cooper, C., \& Fotinos-Riggs, S. D. (1993). A Canadian conversation book: English in everyday life, book one. Scarborough, ON: Prentice-Hall Canada.

Chen, J.-J. (2005). Official knowledge and hegemony: The politics of the textbook deregulation policy in Taiwan. In Y. Nozaki, R. Openshaw, \& A. Luke (Eds.), Struggles over difference: Curriculum, texts, and pedagogy in the Asia-Pacific (pp. 59-77). Albany, NY: State University of New York Press.

Condor, S. (2000). Pride and prejudice: Identity management in English people's talk about "this country." Discourse \& Society, 11(2), 175-205. https://doi.org/10.1177/0957926500011002003

Crenshaw, K. (1991). Mapping the margins: Intersectionality, identity politics, and violence against women of color. Stanford Law Review, 43(6), 1241-1299. https://doi.org/10.2307/1229039

de Cillia, R., Reisigl, M., \& Wodak, R. (1999). The discursive construction of national identities. Discourse \& Society, 10(2), 149-173. https://doi.org/10.1177/0957926599010002002

Derwing, T. M., \& Thomson, R. I. (2005). Citizenship concepts in LINC classrooms. TESL Canada Journal, 23(1), 44-62. https://doi.org/10.18806/tesl.v23i1.77

Duff, P. A., \& Uchida, Y. (1997). The negotiation of teachers' sociocultural identities and practices in postsecondary EFL classrooms. TESOL Quarterly, 31(3), 451-486. https://doi. org $/ 10.2307 / 3587834$

Fleming, D. (2003). Building personal and nation-state identities: Research and practice. TESL Canada Journal, 20(2), 65-79. https://doi.org/10.18806/tesl.v20i2.949

Fleming, D. (2012). Becoming citizens: Racialized conceptions of ESL learners and the Canadian Language Benchmarks. Canadian Journal of Education, 33(3), 588-616.

Goldberg, D. T. (2002). The racial state. Oxford, UK: Blackwell.

Gulliver, T. (2009). Imagining Canada, imagining Canadians: National identity in English as a second language textbooks (Doctoral dissertation, University of Ottawa, Canada). Dissertation Abstracts International, 70(10), AAT NR52332.

Gulliver, T. (2010). Immigrant success stories in ESL textbooks. TESOL Quarterly, 44(4), 725-745. https://doi.org/10.5054/tq.2010.235994

Gulliver, T. (2011). Banal Nationalism in ESL Textbooks. Canadian Journal of Education/Revue Canadienne De L'éducation, 34(3), 119-135.

Gupta, A., \& Ferguson, J. (1997a). Beyond "culture": Space, identity, and the politics of difference. In A. Gupta \& J. Ferguson (Eds.), Culture, power, place: Explorations in critical anthropology (pp. 33-51). Durham, NC: Duke University Press.

Gupta, A., \& Ferguson, J. (1997b). Culture, power, place: Ethnography at the end of an era. In A. Gupta \& J. Ferguson (Eds.), Culture, power, place: Explorations in critical anthropology (pp. 1-32). Durham, NC: Duke University Press.

Ilieva, R. (2000). Exploring culture in texts designed for use in adult ESL classrooms. TESL Canada Journal, 17(2), 50-63. https://doi.org/10.18806/tesl.v17i2.889

Ilieva, R. (2001). Living with ambiguity: Toward culture exploration in adult second-language classrooms. TESL Canada Journal, 19(1), 1-16. https://doi.org/10.18806/tesl.v19i1.916

Kingwell, G., Bonkowski, F. J., Stephenson, L., \& Holmes, T. (2005). Canadian snapshots: Raising issues. Saint-Laurent, QC: Pearson Longman ESL.

Lee, D. B. (2005). New ideologies of everyday life in South Korean language textbooks. In Y. Nozaki, R. Openshaw, \& A. Luke (Eds.), Struggles over difference: Curriculum, texts, and pedagogy in the Asia-Pacific (pp. 117-129). Albany, NY: State University of New York Press.

Liu, Y. (2005). The construction of culture knowledge in Chinese language textbooks: A critical discourse analysis. In Y. Nozaki, R. Openshaw, \& A. Luke (Eds.), Struggles over difference: 
Curriculum, texts, and pedagogy in the Asia-Pacific (pp. 99-115). Albany, NY: State University of New York Press.

Mas, S. (2015, Dec. 14). Truth and Reconciliation offers 94 "calls to action": Commission urges all levels of government to work together and advance reconciliation. Retrieved from http:// www.cbc.ca/news/politics/truth-and-reconciliation-94-calls-to-action-1.3362258

Miles, R., \& Brown, M. (2003). Racism (2nd ed.). New York, NY: Routledge.

Molinsky, S., \& Bliss, B. (1994). Word by word: Picture dictionary. Englewood Cliffs, NJ: PrenticeHall Regents.

Molinsky, S. J., \& Bliss, B. (2001). Side by side student book, book 1 (3rd ed.). White Plains, NY: Prentice Hall Regents.

Montgomery, K. (2005). Banal race-thinking: Ties of blood, Canadian history textbooks and ethnic nationalism. Paedagogica Historica, 41(3), 313-336. https://doi.org/10.1080/00309230500069795

Ndura, E. (2004). ESL and cultural bias: An analysis of elementary through high school textbooks in the Western United States of America. Language, Culture and Curriculum, 17(2), 143-153. https://doi.org/10.1080/07908310408666689

Olsen, J. (1984). Look again pictures for language development and life skills. Englewood Cliffs, NJ: Prentice Hall Regents.

Shapiro, N., \& Adelson-Goldstein, J. (1999). The Oxford picture dictionary: Canadian English edition. New York, NY: Oxford University Press.

Skutnabb-Kangas, T. (2000). Linguistic human rights and teachers of English. In J. K. Hall \& W. G. Eggington (Eds.), The sociopolitics of English language teaching (pp. 22-44). Clevedon, UK: Multilingual Matters.

Stanley, T. (2006). Whose public? Whose memory? Racisms, grand narratives, and Canadian history. In R. W. Sandwell (Ed.), To the past: History education, public memory, and citizenship in Canada (pp. 32-49). Toronto, ON: University of Toronto Press.

Suaysuwan, N., \& Kapitzke, C. (2005). Thai English language textbooks, 1960-2000: Postwar industrial and global changes. In Y. Nozaki, R. Openshaw, \& A. Luke (Eds.), Struggles over difference: Curriculum, texts, and pedagogy in the Asia-Pacific (pp. 79-97). Albany, NY: State University of New York Press.

Swan, M., \& Walter, C. (2001). The good grammar book. Oxford, UK: Oxford University Press.

Thomson, R.I. \& Derwing, T.M. (2004). Presenting Canadian values in LINC: The roles of textbooks and teachers. TESL Canada Journal, 21(2), 17-33. https://doi.org/10.18806/tesl.v21i2.172

Truth and Reconciliation Commission of Canada. (2015a). Canada's residential schools: The legacy. Volume 5 of The Final Report of the Truth and Reconciliation Commission of Canada. Retrieved from www.trc.ca.

Truth and Reconciliation Commission of Canada. (2015b). Honouring the truth, reconciling for the future: Summary of the final report of the Truth and Reconciliation Commission of Canada. Retrieved from http://web-trc.ca/

Truth and Reconciliation Commission of Canada. (2015c). Truth and Reconciliation Commission of Canada: Calls to action. Retrieved from www.trc.ca

van Dijk, T. A. (1992). Discourse and the denial of racism. Discourse \& Society, 3I(1), 87-118. https://doi.org/10.1177/0957926592003001005

van Dijk, T. A. (2001). Critical discourse analysis. In D. Schiffrin, D. Tannen, \& H. E. Hamilton (Eds.), The handbook of discourse analysis (pp. 352-371). Oxford, UK: Blackwell. https://doi. org/10.1002/9780470753460.ch19

van Dijk, T. A. (2002). Discourse and racism. In D. T. Goldberg \& J. Solomos (Eds.), A companion to racial and ethnic studies (pp. 145-159). Oxford, UK: Blackwell.

van Dijk, T. A. (2004, April). Racism, discourse and textbooks: The coverage of immigration in Spanish textbooks. Paper for a symposium on Human Rights in Textbooks, organized by the History Foundation, Istanbul. Retrieved from www.discourses.org/Unpublished articles Teun A van Dijk.html

van Dijk, T. A. (2006). Discourse and manipulation. Discourse \& Society, 17(3), 359-383. https:// doi.org/10.1177/0957926506060250 
White, J. (1997). Listen to the loon: An intermediate listening program. Don Mills, ON: Oxford University Press.

Wodak, R. (2006). Blaming and denying: Pragmatics. In K. Brown (Ed.), Encyclopedia of language \& linguistics, Volume 2 (2nd ed., pp. 59-64). Oxford, UK: Elsevier. https://doi.org/10.1016/ B0-08-044854-2/04307-8

Zuern, G. (2003). Ontario reader 2003 for English as a second language and literacy learners. Toronto, ON: Newcomer Communications.

Zuern, G. (2005). Ontario reader 2005 for English as a second language and literacy learners. Toronto, ON: Newcomer Communications.

Zuern, G. (2007). Ontario reader 2007 for English as a second language and literacy learners. Toronto, ON: Newcomer Communications. 